\title{
Trade union reform in the offing for Hungary's scientists
}

\section{London}

THIS week, some 2,000 Hungarian research institutes, laboratories and scientific establishments have received letters setting out the principles of the proposed new Democratic Trade Union of Scientific Workers. The letter asks scientists and researchers to comment. But officials of the National Trade Union Council (SZOT) have already made their views clear: by drawing Hungary's 77,000 scientists and scholars into a single union, they say, the new body could put at risk the unity of the trade union movement in Hungary.

Hungarian trade unions are organized on the basis of workplace, not profession, so that Hungarian scientists are spread over 16 unions, while in a given institute everyone from scientific director to janitor comes under the same union. During the past few weeks, there has been discussion among the members of the founding committee of the new union as to whether to stay within the SZOT confederation, or whether the new union should become the nucleus of a new professionrelated trade union structure. It is this more radical proposal that alarms SZOT.

In a recent radio interview, Csaba Oeri, one of the founding committee of the new union, said that the situation of scientists and scientific research in Hungary has been "devalued" over the past few years, and that the possibilities of doing effective research are diminishing. These difficulties, Oeri said, predated the present economic difficulties. Nevertheless, the recent cuts in science spending in Hungary may have played some role in triggering the initiative. As the president of the Academy of Sciences, Dr Ivan T. Berend, warned last autumn, the cutback could lead to the closure of institutes and research groups. And, as Oeri pointed out, the new

\section{Thin-film method}

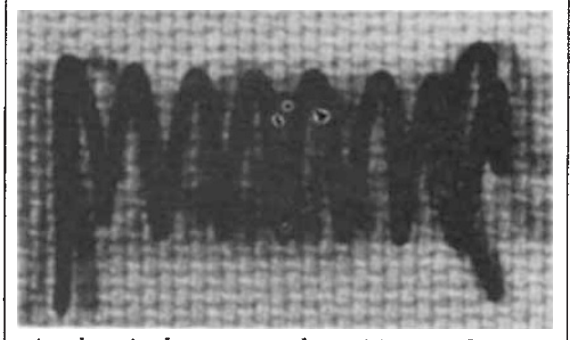

A chemical vapour deposition technique developed by Japanese researchers at Tohuku University and Riken Corporation was used to coat this chrome-nickel coil with yttrium-barium-copper oxide (see Nature 332, 295; 1988). The coil winding is $4.5 \mathrm{~mm}$ across, the chrome-nickel wire $0.35 \mathrm{~mm}$ in diameter, and the superconductor film is about 1 micrometre thick. union would not only look after scientists in employment but also those who lose their jobs.

The scientists' main criticism of the existing union structure is that clashes of different interest groups within a given union make it extremely difficult for the interests of any to be properly represented. The founding committee, said Oeri, supported the idea of "a much more direct and original interest representation" with greater independence for the individual basic organization.

The new union could not, Oeri admitted, form part of SZOT under the latter's present statutes. But the founders, he said, are taking seriously the frequent assertions by SZOT officials that the trade union movement is living in an age of renewal.

The scientists' demands for greater democracy and grass-roots power in the union movement has received some sympathy from Endre Szabo, general secretary of the Trade Union of Public Employees, which includes among its members some 8,000 scientists (including those working in institutes). Although "not convinced" of the need to establish a separate trade union for scientists, he recommended that his union should adopt a "federative" structure, in which the scientists would form an autonomous unit, with complete independence in dealing with matters concerning research institutes. The reactions of the would-be founders of the Democratic Trade Union of Scientific Workers to these compromise proposals have been mixed. Vera Rich - Warsaw university employees are keeping up their campaign for the reestablishment within the university of the banned Solidarity trade union. The courts have so far rejected 27 petitions for the registration of the union, but the 405 person "founding committee" immediately files another application. While the petition for legalization is before the courts, they say, they have some protection against charges of belonging to an illegal organization.

Dr Janusz Onyszkiewicz, a lecturer in mathematical logic, who during Solidarity's legal existence was the union's principal press spokesman, says that in addition to its 405 members, the committee has "several thousand" supporters within the university, more than belong to the "official" trade union. And the movement is gaining quasi-recognition. Last Friday, the committee members and several hundred supporters were able to hold a meeting in one of the largest halls of the university - with the permission of the authorities.

\section{CFCs phased out \\ Washington}

ThE Du Pont Company, the world's largest producer of chlorofluorocarbons (CFCs) last week announced its intention to phase out production of fully halogenated CFCs. The decision comes in response to the report of the Ozone Trends Panel, a committee of the National Aeronautics and Space Administration, to re-evaluate data on global decreases in atmospheric ozone (see Nature 332, 293; 1988). The panel concluded that trace amounts of CFCs in the atmosphere played a role in the stratospheric ozone depletion not explained by sunspot activity.

Du Pont pledged to "continue our aggressive efforts to develop environmentally safe alternatives".

J.P.

\section{US-Japan flight}

\section{Washington}

AN attempt to force renegotiation of the US-Japan nuclear cooperation agreement failed by a vote of 53 to 30 in the US Senate last week.

The agreement, signed in November last year, has been controversial because it gives Japan blanket approval to reprocess spent US-supplied reactor fuel. As Japan does not have reprocessing plants of its own, the agreement allows for spent fuel to be transported to plants in Europe and for purified plutonium to be flown back to Japan via Alaska. The Senate Foreign Relations Committee earlier voted to recommend that the agreement be renegotiated (see Nature 331, 7; 1988).

Opponents of the agreement argue that it loosens US control over the movement of plutonium and thus contravenes the Nuclear Non-Proliferation Act.

The US State Department has agreed that plutonium-carrying planes will not be permitted to fly over Alaska, but will be forced to fly a zigzag route from Europe, up to the North Pole and then down the international dateline to Tokyo, so that the whole flight is above ocean.

A.A.

\section{Merger idea floated \\ London}

THE heads of two of Britain's five research councils are pondering aloud the possible merits of a merger. The financially strapped research councils for Agriculture (AFRC) and the Natural Environment (NERC) point to the overlap of interest in many areas. Advances in many fundamental areas of science, such as molecular biology, have increasingly blurred the traditional divisions of responsibility between the research councils.

Given that the AFRC is to join NERC on the same site in Swindon at the end of the year and that the Advisory Board for the Research Councils is presently examining the research council structure, a change seems likely. 